\title{
INTERFAITH MARRIAGE IN COMPARATIVE PERSPECTIVE
}

\section{RECEP ÇIĞDEM}

The University of Harran, Osman bey Kampusu

Sanliurfa, 63300, Turkey

e-mail: recepcigdem@yahoo.co.uk

This article examines interfaith marriage in different cultures focusing on Islamic law. The modern approach to this social phenomenon is also studied. In order to provide the reader with the legal background, juristic approaches to interfaith marriage are highlighted. Some court cases as well as the universal declaration of human rights and the Cairo declaration of Islamic human rights are examined for this purpose. The article aims at giving a broader perspective on interfaith marriage.

Key words: interfaith marriage, Islamic law, Judaism, Christianity, human rights.

\section{Introduction}

Interfaith marriage refers to marriage between partners professing different religions. Although this type of marriage was not common until the modern age, beginning with the 20th century and the disintegration of the empires, a combination of population, mobility and migration for economic reasons led to an increase in the incidence of such marriages. Economic problems of the third world countries caused the influx of people to migrate to economically prosperous countries. This brought about many problematic issues. One of these issues is mixed marriages. The first generation of immigrants typically did not enter into such unions to the extent that the subsequent generations did. Now one can find instances of a Muslim girl falling in love with a Christian boy or vice versa. ${ }^{1}$ A 2007 Pew Research Center poll of Muslims in America revealed that "fifty-four percent of women and seventy percent of men say inter-

\footnotetext{
${ }^{1}$ Leeman quoting Feuer states that interfaith marriage is discouraged by various religious authorities such as Vatican and Muslim leaders (Feuer 2004; Leeman 2009, pp. 759-761, footnote $150)$.
} 
faith marriage is acceptable" (Leeman 2009, footnote 141). According to the 2006 General Social Survey, $25 \%$ of U.S. households identified themselves as interfaith and approximately one in four Jews and Catholics in the USA marry outside their faith (Qanta, http://usatoday30.usatoday.com/news/opinion/forum/story/2012-02-12/islammuslim-interfaith-marriage/53062730/1).

As a matter of fact, "women who marry non-Muslims may face being disowned by their families ${ }^{2}$ and ostracised by the community" (Leeman 2009, p. 760). Leeman quotes Daily Telegraph (London, September 29, 2003) that a sixteen-year-old Iraqi girl in the United Kingdom was stabbed to death by her father for planning to run away with an eighteen-year-old Lebanese Christian boy. ${ }^{3}$

Since this article is strictly dedicated to religious and legal aspects of such unions, the social and physiological issues will not be examined. ${ }^{4}$

\section{Monotheistic Religions}

\section{A. Judaism}

To begin with, religions do not expect their adherents to tie a bond or get married with a person who professes other religion. Some strictly prohibit interfaith unions. Others may allow it in limited circumstances. ${ }^{5}$

In this respect, the Torah writes: "You shall not make marriages with them, giving your daughter to their sons or taking their daughters for your sons" (The Holy Bible, Deuteronomy, 7:3). Jewish scholars extend this prohibition to non-marital relations. ${ }^{6}$ Intermarriages between Jews and Christians were prohibited by the Emperor Constantinus in 339 and those who did so, were subjected to death penalty. ${ }^{7}$ In 1236 , Moses of Couchy ordered Jews who had married to Christian or Muslim women to break up their marriage. In 1844, the Rabbinical Conference of Brunswick declared:

\footnotetext{
${ }^{2}$ It is reported that a Pakistani Muslim woman who married a Christian was threatened to be killed by her family. (http://www.worthynews.com/9748-pakistan-interfaith-couple-in-hidingamid-death-threats)

3 "A twenty-three-year-old Faten Habash, a Christian living in Palestine, was killed by her Christian father for her desire to marry a Muslim man" (Leeman 2009, p. 760, footnote 148).

${ }^{4}$ For social and physiological issues of interfaith marriage, see Schwartz, http://psychcentral. com/lib/2006/the-emotional-challenges-of-interfaith-marriage/all/1/; Saifuddin, http://peopleofsunnah. com/fiqh/rulings/marriage/80-interfaithmarriage; Lemmons, http://foryourmarriage.org/catholicmarriage/church-teachings/interfaith-marriages/; http://en.wikipedia.org/wiki/Interfaith_marriage_ in_Islam; http://en.wikipedia.org/wiki/Interfaith_marriage_in_Christianity. p. 88).

${ }^{5}$ Only marriage within the same cast is allowed in Hindu custom (Tümer-Küçük 1993,

${ }^{6}$ For more, see http://www.torah.org/learning/halacha-overview/chapter27.html.

${ }^{7}$ There are passages which support intermarriages, such as that of Joseph to Asenath, and that of Ruth to Boaz. The classical Rabbis regard these passages as having occurred only after the foreign spouse had converted to Judaism. No writer, 'Interfaith marriage', (http://en.wikipedia.org/ wiki/Interfaith_marriage\#cite_ref-JewEncInter_3-0; Acar, http://e-dergi.atauni.edu.tr/index.php/ ilahiyat/article/viewFile/3051/2944; Eskan 2007, p. 7).
} 
"The marriage of a Jew with a Christian woman or with any adherent of a monotheistic religion is not prohibited if the children of such issue are permitted by the state to be brought up in the Israelites religion." (http://www.jewishencyclopedia.com/ articles/8137-intermarriage). Modern scholars of Judaism still oppose mixed marriages. Some Rabbis such as Rabbi John Rosove, senior rabbi of Temple Israel of Hollywood, however, are willing to conduct interfaith marriage ceremonies. He is quoted to have said: "My policy of officiating only when both partners were Jewish was based upon voices from Judaic texts and tradition, teachers and mentors who taught me that I was ordained a Rabbi to help fulfill three vital purposes: to preserve the integrity of the Jewish covenantal relationship with God, the viability of the Jewish family, and the survival and continuity of Judaism and the Jewish people. Those voices have sounded inside my head for decades along with the voice that commanded, 'Thou shalt not officiate at an intermarriage ceremony!' ... I've come to the conclusion that based upon the new reality in which we find ourselves and the fact that many intermarried families are seemingly successful in raising their children as Jews here at Temple Israel, I now believe that I can better serve the Jewish people by officiating at their weddings, and that it is time for me to change my policy" (http://www. jewishjournal.com/los_angeles/article/rabbi_reverses_interfaith_marriage_policy).

\section{B. Christianity}

There are different approaches to interfaith marriages in Christianity. Some churches forbid it on the basis of Deuteronomy 7:3, and of 2 Corinthians $6: 14,{ }^{8}$ while others permit it on the ground of 1 Corinthians 7:12-14: "To the rest I say, not the Lord, that if any brother has a wife who is an unbeliever, and she consents to live with him, he should not divorce her. If any woman has a husband who is an unbeliever, and he consents to live with her, she should not divorce her. For the unbelieving husband is consecrated through his wife, and the unbelieving wife is consecrated through her husband."

Walter H. Cuenin, a Catholic chaplain and the co-ordinator of the Interfaith Chaplaincy at Brandeis University offers his approach to interfaith marriage as:

"All decisions about ceremony and children need to take second place to the love relationship of the couple ... For the Catholic, the ceremony can take place in a non-religious setting, and a priest is not even required. It is even possible for the marriage to be done simply by a civil minister, and the church will still recognize it as a valid marriage ... It is very important for me that the couple comes to a decision about which way they will raise the child. Sometimes that decision needs to be based on whichever of the two is the practicing person ... Whatever tradition children are raised in, hopefully they would be exposed to the other faith and

\footnotetext{
${ }^{8}$ The verse reads: "Do not mismate with unbelievers. For what partnership has righteousness and iniquity? Or what fellowship has light with darkness?".
} 
share to some extent in the rituals of that tradition. But as they do that, they need to know their own identity ... The Church recognizes that there may be cases in which the children will be raised in another faith. But the marriage can still go forward. It is always a greater challenge when both parties are well connected to their faith. In some of these situations, when no possible agreement can be reached as to the children's religion, it may even be best if the marriage is postponed or even rethought. It also seems to me that we need to appreciate the good that can come from interfaith marriages. In a strange sort of way, these marriages do remind us that God's call for the human family transcends all religious boundaries. There is no religion that has the only path to God. While we find great benefit in our own faith traditions and want to see them passed on to future generations, no one tradition has an exclusive hold on God's attention. When people of radically different yet connected traditions marry, perhaps they are imaging a new way of viewing life." (Walter, A_Catholic_Priests_Perspective ...)

Ottoman family code which was promulgated in 1917 prohibited the marriage between the different sects of Christianity (Article 29) let alone a different religion. Accordingly, a Catholic may not marry a Protestant (Aydın 1985, p. 248). Article 58 also prohibited marriage between a Muslim woman and a non-Muslim man ${ }^{9}$ and so a Christian lover may not marry his beloved Muslim woman. The opposite is, however, allowed.

\section{Islam}

\section{ORTHODOX APPROACH}

Muslim jurists, except for a few 20th-century scholars, unanimously hold that Muslim women may not marry non-Muslim men. However, Muslim men may marry nonMuslim women of ahl al-kitāb, that is Christians or Jews. ${ }^{10}$ This is the view of Sunni scholars but Shia jurists, however, do not allow Muslim men to marry ahl al-kitāb women in a normal marriage although they allow it in temporary marriage $\left(m u t^{\prime} a\right){ }^{11}$

\footnotetext{
${ }^{9}$ It is worth mentioning that there are Sultanic decrees prohibiting marriage between the Ottoman and the Iranian nationals even though they both share the same religion. This might indicate historical rivalry between the Ottomans and the Iranians. For more see Çiğdem (2011, pp. 45-46).

${ }^{10}$ Some claim that Sabians and Zoroastrians are also ahl al-kitāb. 'Abdurrahman b. 'Awf reports from the Prophet Muhammad: "Deal with the Zoroastrians as ahl al-kitāb, without marrying their wives and not eating their slaughters." It seems that the statement "without marrying their wives and not eating their slaughters" is later added to the hadith. It is reported that Huzayfa, a companion of the prophet married a Zoroastrian woman (Malik b. Anas, Zakat 24; Jassās 1985, Vol. 3, p. 327; Ibn Humām, no date, Vol. 3, pp. 230-232; Kuzgun 1985; Özevin 2006, pp. 13-16; Canan, http://www.hadis.resulullah.org/index.php?s=oku\&id=2969).

${ }^{11}$ For more, see al-Marghinān̄̄ (1986, Vol. 1, p. 193); Ibn Humām (no date, Vol. 3, pp. 228-234); al-Halabī (1981, p. 106); al-Shirbīn̄i (1958, Vol. 3, p. 187); Ibn Rushd (no date, Vol. 2,
} 
If a non-Muslim woman who married a non-Muslim man converts to Islam, the marriage is suspended until her husband converts to Islam. If the non-Muslim husband does convert, a new marriage is not needed. ${ }^{12}$

The second Caliph 'Umar denied interfaith marriage for Muslim men during his rule in 634-644 on the ground that it may open the door to marriage with nonMuslim women leaving Muslim counterparts single. This suggests that 'Umar was rather concerned with the future of Muslim girls. He might have thought that Muslims prefer non-Muslim women for different reasons and not the Muslim girls. This fear led him to temporarily suspend such marriages. ${ }^{13}$

The Muslim jurists based their view on several Qur'anic verses and prophetic traditions ( hadīths). One of these verses reads:

"Do not marry unbelieving women (idolaters), until they believe: A slave woman who believes is better than an unbelieving woman, even though she allures you. Nor marry (your girls) to unbelievers until they believe: A man slave who believes is better than an unbeliever, even though he allures you. Unbelievers do beckon you to the Fire. But Allah beckons by His Grace to the Paradise and forgiveness, and makes His signs clear to mankind: That they may celebrate His praise." (Baqara 2/221)

Another verse:

"O ye who believe! When there come to you believing women refugees, examine (and test) them: Allah knows best as to their Faith: if you ascertain that they are Believers, and then send them not back to the Unbelievers. ${ }^{14}$ They are not lawful (wives) for the Unbelievers, nor are the (Unbelievers) lawful (husbands) for them. But pay the Unbelievers what they have spent (on their dower), and there will be no blame on you if you marry them on payment of their dower to them. But hold not to the guardianship of unbelieving women: ask for what you have spent on their dowers, and let the (Unbelievers) ask for what they have spent (on the dowers of women who come over to you). Such is the command of Allah. He judges (with justice) between you. And Allah is Full of Knowledge and Wisdom." (Mumtahina 60/10)

pp. 33-34); Ibn Qudamā (1992, Vol. 7, pp. 500-503); http://www.sistani.org/index.php?p=741491 $\& \mathrm{id}=56 \& \mathrm{pid}=3263$.

${ }^{12}$ Some scholars have the view that if the wife converts and not the husband, the marriage should not necessarily be cancelled (al-Marghinānī 1986, Vol. 1, p. 220; Ibn Humām, no date, Vol. 3, pp. 418-419; al-Askalān̄i 1407/1986-1987, Vol. 9, p. 333; Karaman 1991, Vol. 3, pp. 383386; Dalgın 2003, p. 146; Dalgin 2005, p. 192; Eskan 2007, pp. 87, 111, 121).

${ }_{13}^{13}$ Ibn al-Humām (d.861/1457) states that 'Umar opposed such marriages on the ground that the mother may influence her children (Ibn Humām, no date, Vol. 3, p. 230; al-Jassās 1985, Vol. 3, pp. 323-325; Sābūnī, no date, Vol. 1, p. 194).

${ }^{14}$ Some Muslim scholars hold that her being Muslim protects her from being deported. This is because the prophet broke the covenant between Muslims and the polytheists of Mecca when a woman named Umm Kulthūm bint 'Uqba sought refuge in Medina, by not returning her to Mecca when her relatives demanded that she be turned back to Mecca (al-Jassās 1985, Vol. 4, pp. 327-330). 
Another verse:

"... and God will never give the unbelievers power over the believers." $\left(\right.$ Nisā 4/141) ${ }^{15}$

The following verse is quoted by the Sunni scholars to base their view that Muslim men may marry to ahl al-kitâb ${ }^{16}$ women:

"This day are (all) things good and pure made lawful unto you. The food of the People of the Book is lawful unto you and yours is lawful unto them. (Lawful unto you in marriage) are (not only) chaste women who are believers, but chaste women among the People of the Book, revealed before your time, when you give them their due dowers, and desire chastity, not lewdness, nor secret intrigues if any one rejects faith, fruitless is his work, and in the Hereafter he will be in the ranks of those who have lost." (Mā'ida 5/5)

Sunni jurists state that this verse clearly gives permission for taking a nonMuslim woman as a wife, it does not, however, do the opposite. They conclude that, in lack of a clear permission, they must be barred from marrying non-Muslim men.

As for the prophetic traditions, the prophet is quoted to have said: "We can marry ahl al-kitāb women, but they cannot marry to our women."17 The following statement is also quoted by the scholars who prohibit interfaith marriage: "Islam is superior; no other religion can be superior over it" (al-Sarakhsī 1986, Vol. 5, p. 45; al-'Ajlūni 1988, Vol. 1, p. 127).

It is reported that Umar dissolved his marriage with Qurayba bint Abi Umayya when she refused to convert Islam after the revelation of Mumtahina 10, however he did not do so when Baqara 2/221 was revealed. He may have understood that this verse is related to the new marriages and not the old ones (al-Askalānī 1407/19861987, Vol. 9, pp. 327-330; Bukhārī 1992, p. 19; Eskan 2007, pp. 84-85).

As for the definition of ahl al-kitāb, according to Hanafis, it refers to those who believe in a revealed book including not only Christians and Jews but also those who believe in Zabūr (Psalms of the Old Testament) and other sheets revealed to Abraham.

\footnotetext{
${ }^{15}$ It seems that this verse is not related to marriage. To quote Leeman "Though frequently cited as justification for the interfaith marriage prohibition, these verses provide only weak support for the position. Following the same interpretation, verse 4:141 would seem to prohibit a Muslim from working for a non-Muslim supervisor, serving in the military under a non-Muslim commander, or perhaps even living in a country with a non-Muslim president. Alternatively, a plain reading of verse 4:141 reveals that the statement refers to the day of resurrection, indicating that Allah will not give unbelievers any advantage over believers at that time" (Leeman 2009, pp. 757-758, footnote 124).

${ }^{16}$ Ahl al-kitāb is not viewed as idolaters (Qur'ān, Baqara 2/105; Āli 'Imran 3/113, 114, Mā'ida 5/5, 82, Hajj 22/17, Bayyina 98/1, 6. Gündüz 2002, p. 245; Acar, http://e-dergi.atauni.edu.tr/ index.php/ilahiyat/article/viewFile/3051/2944).

${ }^{17}$ Acar quotes Muhammad Shākir that this is not a hadith but rather it is a statement of Jâbir, a companion of the Prophet Muhammad (Acar, http://e-dergi.atauni.edu.tr/index.php/ilahiyat/ article/viewFile/3051/2944).
} 
Shafi and Hanbalis hold that it corresponds only to Christians and Jews as the following verse suggests "... the scripture was sent down to only two communities before us ...” (Qur'ān, An'ām 6/156). Zoroastrians are deemed as ahl al-kitāb by Zāhirī and Shia scholars as the following verse separates them from the idolaters: "Indeed those who believe (the Muslims) and the Jews and Sabeans and the Christians and the Magians and the polytheists God will judge between them on the day of resurrection" (Qur'ān, Hāàj 22/17).

Rashīd Rị̣a (d.1354/1935) quoting the verse "we sent to every nation a messenger" (Quran, Nahl 16/36) states that the believers in Brahmanism, Confucianism, Buddhism $^{18}$ and Hinduism are to be considered ahl al-kitāb (Rizā 1367/1948, Vol. VI, pp. 187-188, 193-194). He has the opinion that God specifically prohibited the marriage with the polytheists of Mecca with Baqara 2/221. All other nations have a revealed book even though it may be distorted or altered. This indicates that Muslim scholars do not hold a unanimous view on the question of ahl al-kitāb.

The main reason for the prohibition of marriage between a Muslim woman and a non-Muslim man is the assumption that he may interfere with his wife's religion and keep the children under the influence of his religion (al-Jazīiñ 1986, Vol. 4, pp. 75-76; Bilmen 1985, Vol. 2, pp. 26-27). Fakhr al-Dīn al-Rāzī (d. 606/1209) states that since marriage involves love and intimacy, it may lead to apostasy (Fakhr al-Dīn al-Rāzī 1981, Vol. 6, p. 65; Eskan 2007, p. 77).

Leeman quotes Mashood Baderin:

"[U]nder Islamic law a Muslim man who marries a Christian or Jewish woman has a religious obligation to honor and respect both Christianity and Judaism. Thus the woman's religious beliefs and rights are not in jeopardy through the marriage, because she would be free to maintain and practice her religion as a Christian or Jew. Conversely, a Christian or Jewish man who marries a Muslim woman is not under such an obligation within his own faith, so allowing a Muslim woman to marry a Christian or Jewish man may expose her religious beliefs and rights to jeopardy." (Leeman 2009, p. 758)

Ibn Nujaym (d.970/1562), a Hanafi jurist holds that marrying a non-Muslim woman is makrūh (unpleasant) (Ibn Nujaym 1992, Vol. 3, p. 183). Likewise, Shafi scholars hold that if there is a Muslim woman, marrying to an ahl al-kitāb woman is makrūh (al-Shirbīnī 1958, Vol. 3, p. 187).

Historically, Muslims married ahl al-kitāb women. To quote an Ottoman jurist, Abū'l-Su'ūd (952-982/1545-1574): "If Muslim Zayd dies after marriage to a nonMuslim Hind who has given birth to a child, can Hind marry to non-Muslim. Answer: Yes, but after observing the waiting period. If she was the wife of a non-Muslim, no waiting period is required" (Düzdağ 1972, p. 94). This legal opinion (fatwa) clearly

\footnotetext{
${ }^{18}$ Hamidullah reports that some Muslim scholars see Buddha as Prophet named in the Quran ' $z u$ 'l-kifl'. He suggests that the fig mentioned in the Quran may refer to Buddha who received revelations under the fig tree (Quran, Tīn 95/1; Hamidullah 1991, Vol. 1, p. 649; Tümer-Küçük 1993, pp. $130-132$ ).
} 
shows that Muslims are allowed to marry non-Muslim women. She is free to turn to her fellow believer after divorce or death.

I would like to give one court document which indicates that Muslims in the Ottoman society did in fact married non-Muslim ahl al-kitāb. For example, the ratio of marriage between Muslim men and Jewish women is reported to have been 30\%. ${ }^{19}$ However, I have not come across a case in which a Muslim woman married a nonMuslim man. Although Gradeva states that members of orthodox community took their legal cases to the qādī court despite their being banned from doing so, she does not mention any interfaith marriage case. ${ }^{20}$

The case reads as follows $(69 / 7){ }^{2}$

A man called Ali bey b. Abdullah, an imperial architect, acknowledged that:

He sold his property of which he had the ownership and the disposal until this contract took place between them, to the bearer of this document, his wife, the Christian Dukane bint (the daughter of) Yoni. She purchased and bought it with her own money for herself.

[The sale was related to] the whole of the two houses. One of which is a three storey building having a stable, a water well, a toilet and fruit bearing and some other fruitless trees. It is located in the quarter of Avc1 bey, and it is bounded on two sides by the property of Hasan b. Abdullah, and on one side by the property of Emine hatun bint Hasan and on another side by the heir of the diseased Seyyid Ali çavuş (sergeant).

[It has been sold] together with the appendages, and rights legally appertaining to it.

The price was fixed. Its quantity was twenty thousand dirham (Ottoman silver coins).

The second of which is a two storey building having a toilet and fruit bearing and some other fruitless trees. It is bounded on one side by the property of Haydar Kipti (Gypsy), and on one side by the property of Astoni veled-i (child of) Kosta, and on another side by the city wall of the aforesaid quarter, and on the other side by the public road.

[It has been sold] together with all utilities.

\footnotetext{
${ }^{19}$ Eren quotes Kaya that Jews did not prefer marriage with Muslims as it ousted them from the community. Eren, http://www.aksiyon.com.tr/aksiyon/haber-5370-34-iste-bizim-yahudiler.html; Kaya (1999).

${ }^{20}$ She quotes a firman to this effect. She writes: "A firman addressed to the qādis of Kozluca, Yeni Pazar (Novi Pazar), Hacioglu Pazarcık (all in present day Bulgaria) and Mangalia (in Romania), declaring that all matters of marriage and divorce should be taken to the Bishops of Varna, and not to the Imams of the mahalles and warning of qãdis not to annul the religious penalties imposed by the church courts" (Gradeva 1997, p. 58, footnote 69).

${ }^{21}$ This case is recorded on the register dated 1021-1022 of the Istanbul law court. The number 69 shows the page number; the number 7 indicates the entry on that page.
} 
The price was determined. Its quantity was six thousand dirham cash.

These are legal and valid sales comprising offer and acceptance. [They have been] handed over [to Dukane] and taken over [by her].

Afterwards, they exchanged the money of the aforesaid two houses for the debt of twenty six thousand dirham cash owed by [her husband Ali to her] for a legal loan.

This exchange is legal and valid.

The acknowledgement is valid and legal. The confession is valid and taken into account.

The declaration is confirmed face to face by the person who has the right of confirmation [Dukane].

This happened and was written on 4 Zu'l-hijja 1021/26.01.1613.

This case clearly shows that a Muslim man called Ali bey married a Christian woman named Dukane. He was not an ordinary man, rather he was an imperial architect. It is possible that he was a convert as implied by his patronym 'b. Abdullah' and he may well have originally been a Christian from the same community as the bride. The patronym 'b. Abdullah' was generally given to converts and slaves (Çiğdem 2001, p. 99). This also indicates that Muslim couples were allowed to own properties on their own names as a separate legal entity. Women did not lose their personhood with marriage as the canon law and the old English law prescribed. ${ }^{22}$ This entry also indicates that a woman gave loan to her husband. It is likely that since he was not able to pay the loan back, she took over his belongings, namely two houses. This implies that she was a well-to-do woman. My survey of the Ottoman registers indicates that people took even their close relatives to the court to make them pay their dues (Çiğdem 2001).

\section{The Supreme Court of Massachusetts}

As has been mentioned above, conversion of the wife of the married non-Muslim couples to Islam nullifies the marriage. For example, in a case as old as 1912, Kapigian v. Minassian, the Supreme Court of Massachusetts held as valid the Turkish law of the time which automatically nullified the marriage of a non-Muslim woman to a non-Muslim man upon the wife's conversion to Islam. To quote:

"Husband and wife were married in the U.S. The Husband, a Christian domiciled in Turkey, had previously married in Turkey. The husband's first wife, a Christian at the time of their marriage, had become a Muslim and married a Muslim man. Under Turkish law, when a wife renounced Christianity her previous marriage became void. The second (1966).

${ }^{22}$ For the economic position of married women in pre-Modern English law, see Blackstone 
wife brought a suit against husband asking that their marriage be declared null and void because the husband was not divorced from his first wife. The court dismissed the wife's claim and held that the husband's divorce from his first wife was valid. Citing principles of international law regarding domicile, the court stated that because the husband and his first wife were domiciled in Turkey, Turkish law should govern the validity of their marriage. Turkish law was clear that the marriage is dissolved. And since such law was not contrary to the moral sense of civilized nations, the court should recognize the first marriage as being dissolved. The second marriage was valid because the husband was divorced at the time he married the wife.",23

\section{MODERN ISLAMIC APPROACH}

Contemporary Muslim scholars have different approaches to the marriage of Muslim women to ahl al-kitäb men. ${ }^{24}$ While some oppose, others do not. Karaman and Dağcı quoting Baqara 2/221 and Mumtahina 10 state that Muslim women may not marry ahl al-kitäb men (Karaman 1996, Vol. 1, p. 261; Dağc1 2000, pp. 142-143, footnote 14). Noor Aisha Abdul Rahman reports that Yusuf al-Qardawi has the opinion that interfaith marriage is to be totally prohibited as a precaution. This is nothing more than the reflection of the view of 'Umar, the second caliph (Noor Aisha Abdul Rahman 2009, p. 299).

Topçuoğlu opposes such marriages on the ground that Muslim women may not be able to teach their religion to their children ${ }^{25}$ and the husband may influence his children and brings them up as a Christian or as a Jew (Topçuoğlu 2010, pp. 103109).

Quoting the following verse (Nūr 24/3), Dalgın does not give way to interfaith marriage (Muslim women - ahl al-kitāb men): "The fornicating man shall not marry any but a fornicating woman or an idolatress, and the fornicating woman, no man shall marry her except a fornicating man or an idolater and it is forbidden to the believers. ${ }^{, 26} \mathrm{He}$ considers ahl al-kitāb kāfir/unbeliever or mushrik/polytheist (Dalgın 2003, p. 143). This is not an accurate presentation of the picture of Qur'ān as it names

${ }^{23}$ Kapigian v. Der Minassian, 212 Mass. 412; 99 N.E. 264 (Mass. 1912). Court: Supreme Judicial Court of Massachusetts, Worcester, http://karamah.org/cases/kapigian-v-der-minassian. For the recognition of foreign decrees by the USA state courts see Reed (2003, pp. 107-108).

${ }^{24}$ For more on interfaith marriage see Abdullah An-Na'im, http://www.irandokht.com/ editorial/index4.php?area=wor\&sectionID=24\&editorialID $=2105$.

${ }^{25}$ To quote Mulia: "A survey on interreligious marriage shows that in mixed marriages between Muslim men and non-Muslim women, 50 percent of couples rise their children according to the Islamic faith, while in mixed marriages between Muslim women and non-Muslim men, 80 percent of couples raise their children to follow their mother's religion. This indicates that in interreligious marriages, women have a greater influence than men in deciding their children's religion, contradicting the belief that women are weak and easily tempted" (Mulia 2009, pp. 273-274).

${ }^{26}$ Muslim scholars hold that this verse was abrogated by the verse 32 of the same chapter (al-Jassās 1985, Vol. 3, pp. 106-110; Dalgın 2003, p. 135). 
them as ahl al-kitäb and separates them from these two groups (käfir, mushrik), allowing their marriage and food to Muslims.

He further claims that since Muslim women are not educated, they might be influenced by their husbands (Dalgin 2003, p. 140). This is also not a fact of contemporary time as we know that Muslim women who live in the West are mostly educated and they are aware of the advantages and the disadvantages of such marriages.

He further states that Christianity or Judaism does not give guarantee that there will be no religious propaganda or the wife will not be forced to convert to their religion (Dalgin 2003, p. 150). He ignores the fact that the international and state laws and human rights give such guarantees.

$\mathrm{He}$ stresses that Muslim women may not be able to practise their religion which is a basic human right (Dalgin 2003, pp. 151-152). This is nothing more than an assumption as he provides no data or such a case.

He underlines that like political parties and syndicates which are established or participated by people who share the same or similar values, marriage should be contracted between the people who share the same religion (Dalgin 2003, p. 154). This is also an incorrect analogy as marriage which is based on love, mutual respect and understanding cannot be compared to a social group or a political party which is shared by people who mostly participate for economic and other reasons and do not involve love.

He contradicts himself by allowing a convert Muslim woman to continue her marriage with her non-Muslim husband who refuses to convert to her religion. He, however, does not explain why such a marriage cannot be contracted ab initio (Dalgin 2003 , p. 154). One may ask the question: "If there is such a possibility, why should not it be ab initio?"

Dalgin states that if the prohibition was based on the social conditions of the time of the Muslim jurists (mujtahids), it then must be established as a fact that the conditions for such a marriage has now changed (Dalgin 2003, p. 154). It may not be said that the conditions are fully in favour of such marriages, but it can be said that the conditions in each case need to be investigated and the fatwa is to be based on the merits of each case. If the couple agree that they will respect to each other's religion and will not make any inconvenient comment on the other's religion and will both expose the children to their respective religion without an intervention until they reach puberty and let them choose their religion with their own free will, there should be no problem for such a marriage. If a Muslim woman falls in love with a non-practising Christian man, it should be very easy for her to influence and bring up her children as she wishes.

Güler states that there is no clear Quranic text prohibiting marriage between a Muslim woman and an ahl al-kitäb man. He states that Mumthaina 10 is about the polytheists of Mecca and at that time most of the Jews or Christians were living in Medina and not in Mecca. The unanimous decision about this prohibition is rather based on social and political conditions of the time of the scholars. He, however, agrees with the view of the scholars who are against interfaith marriage (Güler 1997, p. 319).

Muslims in Indonesia adopt a more conservative approach by placing a total ban on interfaith marriage whether he be a Muslim man or woman; this is because 
they do not want to let church authorities marry Muslim women to Christian men. On 1 June 1980, the council of Indonesian ulema issued a fatwa on the ground that the avoidance of peril is to be preferred over obtaining goodness, ${ }^{27}$ forbidding any form of interreligious marriage including the marriage between a Muslim man and a nonMuslim woman, albeit from ahl al-kitäb (Mulia 2009, p. 264; Leeman 2009, p. 769, footnote 207).

In 1989 all major fatwa bodies in Indonesia declared that all marriages between Muslims and non-Muslims are impermissible (Cammack 2009, p. 122). If they were to allow a Muslim man to marry a Christian woman as the classical schools of law do, "they could hardly fault Christian churches for marrying Muslim women to Christian men" (Cammack 2009, p. 131). Suhadi writes "the competition for followers worried the Indonesian Muslim elites who opined that many Muslim convert to other religions by marriage. I believe this is the central idea behind the prohibition of interreligious marriage in Modern Indonesia" (Cholil 2009, p. 148). The statics of conversion worries Muslim elites. Cholil states "from April 1985 to July 1986, 239 Muslimnon-Muslim marriages were registered in the civil Registry in Jakarta district, ${ }^{28}$ out of which 112 involved Muslim men marrying non-Muslim women and 127 cases involved Muslim women marrying non-Muslim men" (Cholil 2009, p. 154). ${ }^{29}$ In 1991, the presidential instruction prohibited Muslim-non-Muslim marriages in Indonesia (Cholil 2009, p. 154). Mulia underlines that since lovers of different religions are not able to get a marriage certificate, they go abroad such as Singapore and Australia in order to get married. Their marriage certificate is registered by the National Civil Registry office in Indonesia without even questioning the form of the union (Mulia 2009 , p. 265).

Let us now see the view of the scholars who are in favour of such marriages. One of the scholars who permit such marriages is Huseyin Atay. He states that marriage and its conditions were specified by the Muslim jurists in accordance with the social conditions of their time. These are not based on religious texts and so marrying a Christian woman does not invalidate the marriage contract neither does the marriage of a Muslim woman with a Christian man (Atay 1993, pp. 58-59, 61-63; Eskan 2007, pp. 92-93). Islam recognises the marriage of non-Muslims and so it should recognise the marriage of a Muslim woman with an ahl al-kitāb man. He further underlines that Muslim women in the West are not able to wed to Muslim men as they prefer nonMuslim girls which leads Muslim women to experience many difficulties and to live under torture. Islam does not condone torture and was no revealed to have Muslim women suffered. In addition, he states that if Muslim women are conscious and aware of their religious values, they may able to influence their non-Muslim husbands. Such marriage is not to be considered as losing one person (Muslim woman) but gaining another person (non-Muslim man). He concludes that the marriage of a Muslim woman

\footnotetext{
${ }^{27}$ For the explanation of this rule, see Ibn Nujaym (1985, Vol. 1, p. 290).

${ }^{28}$ On the reasons of conversion, see Peker (1979); Kökelekli-C Cayır (2006, pp. 23-46).

${ }^{29}$ For interfaith marriage, see http://www.interfaithshaadi.org/index.php?option=com_content $\&$ view $=$ category $\&$ id $=77 \&$ Itemid $=78$.
} 
with an ahl al-kitāb man is valid (Atay 1993, pp. 58-59, 61-63; Acar, http://e-dergi. atauni.edu.tr/index.php/ilahiyat/article/viewFile/ 3051/2944).

Another scholar who is in favour of such marriages is Bilgin who holds that there is no prohibition on the marriage of a Muslim woman with an ahl al-kitāb man. If there was a real prohibition, the punishment of zina (fornication) should have been carried out. But this was not the case. Since there is no clear judgement, the decision in favour of permission should be made. She concludes that Muslim women are permitted to marry ahl al-kitāb men and that they need to solve their social problems with a mutual agreement (Bilgin 2001, p. 29; Eskan 2007, pp. 91-92).

Ateş, who is also in favour of such marriages, states that Quran (Māida 5) is silent about the marriage of a Muslim woman with an ahl al-kitäb man and that $a h l$ $a l-k i t a \bar{b}$ is not mushrik (polytheist). He underlines that Quran prohibits the marriage of a Muslim man or a woman with a polytheist and that considering ahl al-kitāb as mushrik is against the clear judgement of Qur'ān. He pays attention to the social facts of modern time by stating that it is a fact that women and girls who live in the West are getting married to their colleagues or school mates. Answering a question in his column in a newspaper, he concludes "we cannot ignore such marriages. Qur'ān does not clearly state that Muslim women may marry ahl al-kitāb. It does not either state that Muslim women cannot marry ahl al-kitāb men. If you believe that he is a monotheist, there is no problem in your marriage to him. But, take care of your children about your religion" (Ateş 03.02.2006).

Acar states that Qur'ann is silent about the marriage of Muslim women with non-Muslim men. He underlines that Mumtahina 10 prohibits the marriage of a Muslim woman with a polytheist man but it does not prohibit the marriage with an ahl alkitāb man. He further highlights that it is not possible to state that Baqara 221 forbids the marriage of Muslim women with ahl al-kitāb men. He emphasises that this verse prohibits only the marriage of Muslim women with the polytheists. He stresses that the reasons put forward by the Muslim scholars about the prohibition of marriage between Muslim women and ahl al-kitäb men are rather related to the patriarchal society and to the social conditions of their time and that these are not relevant to our society. He draws attention to the fact that it is not possible for educated women of our time who share all aspects of life and actively participate in social life to be pressurised by their husbands (Acar, http://e-dergi.atauni.edu.tr/index.php/ilahiyat/article/ viewFile/3051/2944).

In her $\mathrm{PhD}$ thesis dedicated to interfaith marriage, Eskan states that Mumtahina 10 concerns the polytheists of Mecca as indicated by the definite article lam-l ta 'rif (al) of al-Kawafir referring to the agreement concluded in Hudaybiya between the Muslims and the polytheists of Mecca. She stresses that this verse does not say anything about ahl al-kitäb, and that the prohibition of marriage between Muslim women and ahl al-kitāb men cannot be based on this verse (Eskan 2007, pp. 84-85). In addition, she underlines that Mumtahina 10 is about women who sought refuge in Medina and it does not say anything about Muslim women who preferred to live with their polytheist husbands without seeking refuge. The statement "But hold not to the guardianship of unbelieving women: ask for what you have spent on their dowers, and let 
the (Unbelievers) ask for what they have spent (on the dowers of women who come over to you,") indicates that this prohibition was based on reciprocity (Eskan 2007, p. 86). She quotes Aktan that there were Muslim women who continued to live with their polytheist husbands even after the conquest of Mecca, implying that difference of religion is not an impediment to marriage (Aktan 2002, p. 295; Eskan 2007, p. 86).

She further quotes Aktan that Mumtahina 10 refers to freedom of religion. If a Muslim woman seeks refuge in a Muslim country and wishes to dissolve the marriage, her wish should be honoured and her dower should be returned to her non-Muslim husband. Likewise, if a Muslim woman converts to another religion and seeks refuge in a non-Muslim country dissolving the marriage, her desire and choice should be respected and her dower should be returned to her Muslim husband (Aktan 2002, p. 295; Eskan 2007, pp. 120-121). She further quotes Aktan that at the time of the prophet, when the wife converted Islam and the husband did not, the marriage was not dissolved and that since these rules are based on ijtihäd (personal reasoning), the facts of life need to be taken into account (Aktan 2002, p. 307; Eskan 2007, p. 123).

She quotes Qur'ân that the spouses of Noah and Lot were unbelievers but the wife of the Pharaoh was a believer suggesting that Quran did not envisage religion as a bar to marriage (Qur'ān, Tahrīm 66/10-11; Eskan 2007, p. 87). Quoting the verse "lawful for you are (all women) besides those" (Nisā 4/24), she states that ahl al-kitāb men is lawful for Muslim women. She suggests that this general permission (Nisā 4/24) may have abrogated Baqara 2/221 or may have limited it to the polytheists. In her view, Mā'ida 5 was revealed in order to make it clear that ahl al-kitāb women are permitted to Muslim men. This is due to the fact that some companions of the Prophet thought that they had been prohibited to them (Eskan 2007, p. 88).

She quotes Görmez, the head of the directorate of the religious affairs, that the prohibition of interfaith marriage (Muslim women-ahl al-kitāb men) was based on ijm $\bar{a}$ ' (consensus of the Muslim scholars) but not on Qur'ān or Sunna and that since the scholars did not want Muslim women to be assimilated, they abolished the permission of marriage (Eskan 2007, p. 103).

She defends equality between men and women refuting the claim that Muslim women may lose their religion in such marriages. Having analysed the juristic views, she concludes that marriage is a contract which can be made between a Muslim woman and an ahl al-kitäb man (Eskan 2007, pp. 98-103).

Now I would like quote Abū'l-Fadl, "I am not aware of a single dissenting opinion on this, which is rather unusual for Islamic jurisprudence because Muslim jurists often disagreed on many issues, but this is not one of them" (Leeman 2009, p. 756). Leeman states, "Abū'l-Fadl's observation is significant because the Qur'ân is not unambiguously clear on this issue. Therefore, construing Islamic law to prohibit interfaith marriage for Muslim women requires an appeal to some extra-Quranic source to supplement Qur'ānic verse. Each verse that prohibits interfaith marriage specifically refers to mushrik, the class of unbelievers that includes polytheists, idolaters, and atheists. These verses do not prohibit marriage to People of the Book" (Leeman 2009, p. 756). He quotes Dr. Khaleel Mohammed who "claims that the traditional interpretation of the Qur'ān banning interfaith marriage for women is based on 
the historical assumption that a woman must accept the religion of her husband... Muslim women today live in a different time and a different place... women are equals of men... women have legal rights...those rights include placing conditions on the marriage... ${ }^{30}$ an inter-faith marriage can take place on condition that neither spouse will be forcibly converted to the other's religion" (Leeman 2009, p. 762). He also quotes Abdullahi Ahmed An-Naim, "in social reality today, men are not dominant in the marriage relationship. The rationale of historic rule is no longer valid" (Leeman 2009 , p. 763).

Leeman writes: "Sudanese Islamist leader Dr. Hassan al-Turabī also recently issued a fatwa authorizing marriages between Muslim women and Christian and Jewish men. In so doing, Dr. al-Turabī specifically rejected the traditional position that the absence of a specific authorization in the Qur'ann makes these marriages illegal. To the contrary, al-Turabī declared that he could not find a single word that prohibited such marriage in either the Qur'ān or the Sunna. This is a bold statement, considering the Qur'ān's general prohibition of marriages to unbelievers. Al-Turabī argues that marriages between Muslim women and Christian or Jewish men warrant a case-by-case evaluation, and rejects the idea that consensus among Islamic scholars made the interfaith marriage prohibition universally binding. He insists that marriage between a Muslim woman and a non-Muslim man is valid since nothing in the Qur'ān or the Sunna dictates otherwise" (Leeman 2009, p. 763).

Mulia states that interreligious marriage is a matter of ijtihād and "there is no verse in the Qur'ān that firmly and resolutely forbids or allows interreligious marriage. If there is no clear law, the original law is that it is permitted" (Mulia 2009, p. 274). She holds that ijtiha $\bar{d}$ which is based on one's understanding of religious text is generally influenced by the social and otherwise conditions of that mujtahid (jurist) and may not fit to another society (Mulia 2009, pp. 275-276). She writes "unlike men, all women are assumed to be weak in their faith. This view is clearly biased in terms of gender and patriarchal values as it is based on stereotyping a woman a weak being whose belief is easily shaken. So, according to the logic of this stereotyping, Muslim women are advised not to marry non-Muslim men, including those from the ahl al-kitāb" (Mulia 2009, p. 268). She states that under her co-ordination she proposed a legal draft regarding interreligious marriage: ${ }^{31}$

"A marriage between a Muslim and a non-Muslim person or interreligious marriage is unconditionally allowed; marriage between a Muslim and a non-Muslim shall be conducted based on the principle of mutual respect and appreciation of rights of freedom to perform their respective religious teachings and belief; before the marriage is performed, the Government shall provide explanation to the groom and bride concerning

${ }^{30}$ Hanbalis allow prospective marriage partners to place conditions upon the marriage contract. This was also accepted by the Ottoman family code, Article 38 (Ibn Qudamā 1992, Vol. 7, pp. 448-449).

${ }^{31}$ She states that interreligious marriage may produce domestic violence and trafficking of women and children causing social unrest (Mulia 2009, p. 274). 
issues that arise in marriages between a Muslim and non-Muslim so that each party is aware of these issues; in a marriage between Muslim and non-Muslim, children have the right to choose their desired religion and adhere to it; and in the event that the children have not been capable of determining their religion of choice, their religion should be decided by their parents, with mutual consent of parents and children." (Mulia 2009, p. 279)

Suhadi reiterates the above statement of Mulia reporting, "in 2004, some progressive Muslim groups, led by Siti Musdah Mulia, proposed, in response to the CIL (Compilation of Islamic law), a counter legal draft (CLD) which, among other things, permitted Muslim-non-Muslim marriage for male as well as female Muslims. Article 54 of the CLD states: (1) Muslim-non-Muslim marriage is permitted. (2) Muslimnon-Muslim marriage is carried out based on a principle of appreciation and respect for the rights of religious freedom of each other" (Cholil 2009, p. 155). Since MUI (the Majelis Ulama Indonesia) and MMI (Indonesian Mujahidin Council) rejected the motion of CLD, it was not incorporated into the law. He concludes, "the debate on Muslim-non-Muslim marriage is shifting from an interreligious debate between Muslims and Christians in the early 1970s, to a debate within interreligious groups, as well as between conservative and moderate Islamic groups" (Cholil 2009, p. 155).

Noor Aisha Abdul Rahman reports that a qādi in Singapore annulled the marriage of a Muslim man to a Christian woman on the ground that "the wife was, at the time of marriage, a Christian whose ancestors had converted to Christianity after the coming of the prophet Muhammad" (Noor Aisha 2009, p. 296). She criticises the ruling as it did not consider the burden of proof and whether it was possible for her to find out when her ancestors converted to Christianity. She quotes attorney general of the time, Ahmad Ibrahim "it is undoubtedly true that marriage with a non-Muslim is frowned upon in Muslim law. The reasons for as pointed out by Syed Ameer Ali are largely historical. Difference of religion implied in earlier times hostility to the commonwealth of Islam and apostasy was regarded tantamount to treason. In modern society in which Muslims and non-Muslims live together in fraternity as fellow citizens of the state with equal rights and responsibilities it seems fair and equitable that men and women of full age should have the right to marry and have a family without any limitation due to race, nationality or religion; and so it is provided in the universal declaration of human rights. It is perhaps a matter of regret that the Shariah Court in Singapore has sanctioned rather arbitrarily, a view on this matter which is even more restrictive than is generally believed to be the case under the Muslim law" (Noor Aisha 2009, p. 298).

I would now like to go over the Qur'anic verses and the historical facts. To begin with, analysis of different verses and the historical facts suggest that if marriage is based on mutual love, respect and understanding, religion (Muslim women-ahl alkitāb men) is not to be seen as an impediment to marriage; although the marriage union composed of the same religion would be better.

Mumtahina 10 is rather about women who sought refuge in Medina and wanted to dissolve their marriage. It was not revealed in order to enumerate the impediments 
of marriage. These were enumerated in another chapter (Nisā 4/23-24) which says nothing about interfaith marriage. The statement "except for these, all others are lawful" may indicate that interfaith marriage is permitted.

There are verses which suggest that marriage is to be based on mutual love. One of them goes:

"And among His wonders is this: He creates for you mates out of your own kind, so that you might incline towards them, and He engenders love and tenderness between you: in this, behold, there are messages indeed for people who think." (Rūm 30/21)

This verse might imply that if the marriage is based on love, mutual respect and understanding, and partners feel comfort with this union, and respect to each other's religion, the difference of religion should not be a barrier to marriage.

Another verse goes:

"And God sets forth an example to those who believe, the wife of Pharaoh when she said, 'My Lord!, built for me a house with you in the paradise and save me from Pharaoh and his evil deeds, and save me from the unjust people'." (Tahrīm 66/11)

This suggests that a believer woman may marry to an unbeliever and follow her own religion. If she is able to keep her faith under a tyrant ruler like a Pharaoh, why should not she keep it with a respectful and understanding lover?

Another important verse reads:

"Do not marry unbelieving women (idolaters), until they believe: A slave woman who believes is better than an unbelieving woman, even though she allures you. Nor marry (your girls) to unbelievers until they believe: A man slave who believes is better than an unbeliever, even though he allures you. Unbelievers do (but) beckon you to the Fire. But Allah beckons by His Grace to the Garden (of Bliss) and forgiveness, and makes His Signs clear to mankind: That they may celebrate His praise." (Baqara 2/221)

Here, we need to underline the statement: "Unbelievers do beckon you to the Fire", as this indicates that the reason for the prohibition of such marriage is their insistence on their call to their religion. If there is a possibility that man will put pressure on the wife to change her religion, the marriage may not be allowed. If there is no such possibility, and if she feels free in practising her religion, there should not be a problem in such marriage.

It is also worth quoting the following verse:

"This day are (all) things good and pure made lawful unto you. The food of the People of the Book is lawful unto you and yours is lawful unto them. (Lawful unto you in marriage) are (not only) chaste women who are believers, but chaste women among the People of the Book, revealed before your time - when ye give them their due dowers, and desire chas- 
tity, not lewdness, nor secret intrigues, if any one rejects faith, fruitless is his work, and in the Hereafter he will be in the ranks of those who have lost." (Māida 5/5)

We need to underline the following statement "if any one rejects faith, fruitless is his work" as it stresses the importance of religion and underlines that no one is to interfere with the other's religion. According to this statement, both need to keep their own respective religions. This suggests that Muslim man needs to follow his own religion and not to be influenced by his wife regarding his religion. Likewise, Muslim woman has to follow her own religion and not to be influenced by her husband.

Another verse goes:

"Women impure are for men impure, and men impure for women impure and women of purity are for men of purity, and men of purity are for women of purity: these are innocent of all what people say: for them there is forgiveness and a provision honorable." (Nūr 24/26)

This verse emphasises the importance of purity of couples, suggesting that people should choose their future partners from the pure/honourable people. This, however, does not say anything about the religion of the couples.

The last Qur'anic verse which I would like to quote here is the following:

"Do not marry unbelieving women (idolaters), until they believe: A slave woman who believes is better (khayr) than an unbelieving woman, even though she allures you. Nor marry (your girls) to unbelievers until they believe: A man slave who believes is better than an unbeliever, even though he allures you. Unbelievers do (but) beckon you to the Fire. But Allah beckons by His Grace to the Garden (of Bliss) and forgiveness, and makes His Signs clear to mankind: That they may celebrate His praise." (Baqara $2 / 221$ )

Here, the adjective 'better (khayr)' and the verb 'allures ('ajabatkum)' need to be underlined. These two phrases clearly indicate that it would be better to marry a fellow believer and that there is no impediment if they wish to do otherwise.

It is worth mentioning an important historical fact about the interfaith marriage. Zainab, the daughter of the Prophet migrated to Medina leaving her husband Ali Abi al-As b. Rabi in Mecca as he was a polytheist. They lived separately for six years. When her husband converted to Islam, the prophet returned his daughter to her husband without a new marriage contract ${ }^{32}$ although it was after the revelation of 2/221 which prohibited the marriage between Muslim women and the polytheists. This may indicate that conversion to Islam does not invalidate the contract. If it was, the prophet would have demanded a new contract of marriage. If the conversion does not invalidate such a marriage, why should such a marriage do so ab initio.

${ }^{32}$ Al-Jassās states that there is a report that the Prophet returned her with a new contract of marriage (al-Jassās 1985, Vol. 5, p. 331; Ibn Qudāma 1992, Vol. 7, pp. 536-537; Ibn Humām, no date, Vol. 3, pp. 425-426). 
The assumption that the father may influence his children on religion is correct. It is equally correct that the mother may influence her children. If we take only one side, we may overlook the other. Not only the father but also the mother may have influences on children. In a statement attributed to the Prophet, both the father and the mother have influences on children. The statement goes:

"Every new-born child is born in a state of fitrah (natural disposition of mankind). Then his parents make him a Jew, a Christian or a Magian, just as an animal is born intact. Do you observe any among them that are maimed (at birth)?" (Bukhārī, Janāiz 92; al-Askalānī 1407/19861987, Vol. 3, pp. 290-295)

In the contemporary age, there are many ways to obtain information about religion. The children can get accurate information on their parent's religion through various sources (internet, book, tv etc.) and choose it with their own free will. According to Muslim scholars, religion needs to be chosen on free will (Ramazan efendi, no date, p. 262). Adoption of the faith of parents without questioning is refuted by Qur'ān:

"And whenever it is said to them (the unbelievers), follow what God has sent down, they say, rather we follow what we found our fathers to follow. Even though their fathers had no sense at all, nor did they follow the right path." (Baqara 2/170);

"And when it is said to them come to what God has revealed to the Messenger, they say, what we found our ancestors doing is sufficient for us, even though their ancestors knew nothing and were misguided." (Mā'ida $5 / 104)$

If a non-Muslim wife is able to follow her religion and get rid of the pressures of her Muslim husband, why a Muslim woman should not keep her religion during her marriage with an ahl al-kitāb man. As Qur'ān said, guidance to the truth lies with God: "Indeed, you cannot guide whom you love, but God guides whom he will, and He knows those who deserve to be guided" (Qasās 28/56).

It is worth underlining that interfaith marriage may lead the man to understand his wife's religion and even if he does not convert, he may not feel hostility towards Muslims. The adverb "people are enmity with unknowns" clearly indicates that presenting Islam to an alien will definitely turn out with positive outcomes.

It seems that whether male or female under the non-Muslim or Muslim follows his/her religion and does good deeds s/he will get heavenly reward and his/her marriage is valid. To quote the Qur'ān:

1. "Humankind was of a single community/nation/religion..." (Baqara 2/213).

2. "O believe! Indeed, we have created you of a male and female and made you nations and tribes in order that you may know each other. Indeed, the most honorable of you with God, is the one among you, most careful of his duty (taqwa) to God" (Hujurāt 49/13). 
3. "Indeed, I will not waste the work of a worker among you, whether male or female; you are equal in my mercy and forgiveness" ("Āli Imrān 3/195).

4. "Moreover, whoever does good deeds, whether male or female, and he (or she) is a believer, these shall enter the paradise, and they shall not be wronged the husk of a date stone" (Nisā 4/124).

5. "Indeed, those who believe, and the Jews, and the Christians, and the Sabians, whoever believes in God and the last day, and does good, they shall have their reward from their Lord, and there is no fear for them, nor shall they grieve" (Baqara 2/62).

6. "Indeed, those who believe, and the Jews, and the Sabians, and the Christians, whoever believes in God and the last day, and does good, they shall have their reward from their Lord, and there is no fear for them, nor shall they grieve" (Mā'ida 5/69).

If anyone blasphemes whether married or single and whether under the Muslim or non-Muslim, s/he will get the hell fire as Qur'ān writes: "Whoever of you revokes his religion, he then dies as an unbeliever; those who do that, their deeds will be void in this world and the hereafter..." (Baqara 2/217).

\section{Human Rights, National Laws and Some Court Cases}

The Universal Declaration of Human Rights which is agreed to be the foundation of international human rights law and adopted in 1948, clearly protects couples from the interference of each other's religion. In addition, according to this declaration, difference of religion is not to be an impediment to marriage. The important articles of this declaration read:

"All are equal before the law and are entitled without any discrimination to equal protection of the law. All are entitled to equal protection against any discrimination in violation of this declaration and against any incitement to such discrimination." (Article 7)

"No one shall be subjected to arbitrary interference with his privacy, family, home or correspondence, nor to attacks upon his honor and reputation. Everyone has the right to the protection of the law against such interference or attacks." (Article 12)

"Men and women of full age, without any limitation due to race, nationality or religion, have the right to marry and to found a family. They are entitled to equal rights as to marriage, during marriage and at its dissolution. Marriage shall be entered into only with the free and full consent of the intending spouses. The family is the natural and fundamental group unit of society and is entitled to protection by society and the State." (Article 16) 
"Everyone has the right to freedom of thought, conscience and religion; this right includes freedom to change his religion or belief, and freedom, either alone or in community with others and in public or private, to manifest his religion or belief in teaching, practice, worship and observance." (Article 18)

The Cairo Declaration of Human Rights, a declaration of the member states of the Organisation of the Islamic Conference adopted in Cairo in 1990 gives men and women the right to marriage regardless of their race, color or nationality, but not religion. Article 6 is in contradiction with Article 5 as the former specifies equality between men and women but the latter revokes it by not allowing women to marry nonMuslims. Article 6 clearly states: "Woman is equal to man in human dignity, and has her own rights to enjoy as well as duties to perform, and has her own civil entity and financial independence, and the right to retain her name and lineage." Article 5 is contradiction with this one as it remains silent on interfaith marriage: "The family is the foundation of society, and marriage is the basis of making a family. Men and women have the right to marriage, and no restrictions stemming from race, color or nationality shall prevent them from exercising this right."

I would now like to go over contemporary national laws. Turkish law does not see religion as an impediment to marriage (Turkish civil law, Articles 129, 130, 145). Likewise, USA state laws permit interfaith marriage (Oliphant-Steegh 2007, pp. 32-38). English law also allows the marriage of different faiths (Cretney-Masson 1997, pp. 42-48). Japanese civil code does not enumerate religion among the impediments to marriage. Indian secular law is also silent about interfaith marriage (Articles 732-741). ${ }^{33}$ Indian Muslims follow the Muslim Personal Law (Shariat) Application Act, 1937 which prohibits Muslim women from marrying non-Muslim men.

Following the Shia school of law, Iranian law does not allow interfaith marriage between a Muslim woman and a non-Muslim man. However, it is silent about the marriage between a Muslim man and an ahl al-kitāb woman which is prohibited by Shia scholars (http://www.sistani.org/index.php?p=741491\&id =56\&pid=3263). The Iranian civil code (Article 1059) states: "Marriage of a female Muslim with a nonMuslim is not allowed" (http://www.alaviandassociates.com/documents/civilcode.pdf).

Pakistani family law also does not allow a Muslim woman to marry a non-Muslim man but the opposite is permitted as long as the woman is from ahl al-kitāb. ${ }^{34}$

${ }^{33}$ To quote "the fact remains that in India when young men and women marry outside their castes or community, it evokes strong sentiments and even honor killings, even though there is no bar to inter caste marriages under any codified marriage law. In one such recent decision rendered by the Indian Supreme Court in Lata Singh vs State of UP, reported at Judgments Today 2006(6) SC, 173, it was held that the caste system is a curse on the nation and needs to be destroyed for the better." (Anil Malhotra-Ranjit, http://www.iaml.org/cms_media/files/family_law_and_religion_ the indian_experience.pdf).

${ }^{34}$ For news about the marriage of Muslim women with non-Muslim ahl al-kitāb men, see http://www.asianews.it/news-en/Muslim-woman-forced-to-flee-for-marrying-a-Christian-22162.html. This page quotes a Pakistani scholar named Maulana Muhammad Sultan Haider: "This does not change anything. Only a Muslim man can marry a non-Muslim woman, because it would water 
Malaysian Islamic Family Law (Federal Territories) Act 1984 states: "No man shall marry a non-Muslim except ahl al-kitāb. No woman shall marry a non-Muslim... A marriage in contravention of this Act shall not be registerable under this Act" (Mohamad-Aziz-Sim 2009, p. 72; http://www.agc.gov.my/Akta/Vol.\%207/Act\% 20303. pdf). ${ }^{35}$

As for Indonesia, its civil code (Article 26) writes: "The law shall only recognize a marriage in a civil relationship" (http://www.unhcr.org/refworld/pdfid/3ffbd0804. pdf). It is silent about the interfaith marriage. However, Indonesian Islamic family code does not allow a Muslim woman to marry a non-Muslim man but the opposite is permitted as long as the woman is from ahl al-kitäb. Lukito and Mark state that Article 2/1 does not forbid the marriage between two different religious groups (Lukito 2009, p. 35; Cammack 2009, p. 102). Lukito quotes a group which states that "the government cannot thus make any law or regulation outlawing interfaith marriage because it is a human right that every state should recognize" (Lukito 2009, p. 38).

The council of Indonesian 'ulama in Jakarta issued a fatwa on 30 September 1986 allowing interreligious marriage whether he be a Muslim man marrying a nonMuslim woman or a Muslim woman marrying a non-Muslim man. They revoked their fatwa in 2000 declaring that all interreligious marriages are forbidden (Mulia 2009, pp. 271, 273).

\section{The Supreme Court of Indonesia}

Lukito reports and analyses an important legal case about interfaith marriage. In this case, a Muslim woman named Andy Vony Gani Parengi married to a Christian man by the name of Adrianus Petrus Hendrik Nelwan in 1986 and wanted their marriage be registered. The authorities, (the Office of Religious Affairs/KUA and the Civil Registration Office/KCS) rejected their application. They applied to the court to get KCS to register their marriage. The primary court judges rejected their application to the court on the ground that the marriage law of No 1 of 1974 does not regulate interfaith marriage and Islam (Qur'ān 2/221) and the new testament (2 Corinthians 6:14) disallow the interfaith marriage. She appealed against this judgement arguing that her marriage to Adrianus was based on mutual love and that their parents approved of their marriage and there was no clear prohibition of interfaith marriage according to the marriage law. The Supreme Court judges accepted her argument and quashed the decision of the lower court judges on the ground that they loved each other and that their parents did not oppose to the marriage. In the view of the judges, outlawing the interfaith marriage is against the 27 th article of the constitution of

\footnotetext{
down future generations. I condemn this marriage, I call it illegal, and these two could be killed for what they did."

${ }^{35}$ Maznah states that the friction between the advocates of sharia and the secular laws cost to "the ethnic peace and human liberty; not to mention private happiness" (Mohamad-Aziz-Sim 2009, p. 94) 
$1945^{36}$ which gives equal protection to the citizens of the country on marriage regardless of their religious affiliations. The judges also turned to human rights to base their decision. Since the two parties had the same nationality, it was the responsibility of the state to protect their basic human right to marry any other Indonesian citizen. The court also took into account the frequency of interfaith marriage in the Indonesian society, concluding that interfaith marriage is possible by law. The judges ordered the KCK to register the marriage of Vony to Adrinaus (Lukito 2009, pp. 45-49).

Lukito underlines that the Supreme Court did not take the case as a religious matter but examined it in the perspective of human rights. He emphasises that taking Article 27 of the constitution as a ground for interfaith marriage is a weak argument as it does not say anything about interfaith marriage. In his view, this argument can have weight if it is supported by other considerations (Lukito 2009, p. 50).

Mark reports that on 1 January 1989, three weeks before the decision of the supreme court, "the Jakarta civil registry adopted the policy that civil marriages would no longer be recognized", requiring that all marriages be performed by religious officials putting an end to the civil marriages turned to by couples of different religious affiliations (Cammack 2009, p. 119). In a circular letter dated 17 April 1989, the minister for home Affairs proclaimed that only religious marriages would be recognised and that civil registry would register the marriages performed by religious authorities (Cammack 2009, pp. 120-121). He states that he spoke to the officials in 2006 who told him that "only marriages between persons who share the same religion can be recorded and that in case in which the identity cards of the parties indicate different religions, proof of conversion is required before the marriage can be recorded" (Cammack 2009 , p. 125). He further quotes church officials that "the civil registry sometimes records marriages of mixed religion couples without proof of conversion if the non-member party to the marriage promises to permit the member spouse and the couple's children to continue to practice the religion" (Cammack 2009, pp. 125126). He states that the law which was approved in December 2006 makes interfaith marriages more easily contracted (Cammack 2009, p. 126). He underlines that postSuharto constitutional changes such as 28 (B) which guarantees the right to form a family might be used to challenge the ban on interfaith marriages or limitations on the right to marry (Cammack 2009, p. 128).

\section{Society and the Interfaith Marriage}

Interreligious marriages carry heavy social responsibilities. The couples need to be ready to be ostracised by the society. To quote Jolanda reporting from a Chinese female who married a Muslim man: "My mother could not accept it, my brothers and other relatives could not and actually could not accept it. It was hard for me, really

\footnotetext{
${ }^{36}$ This article reads: "All citizens have equal status before the law and in government and shall abide by the law and the government without any exception" (Lukito 2009, p. 56).
} 
hard, because I am the only daughter. My mother did not agree and my father had already passed away. It was like I was alone, no one to talk to. I could not talk to my friends at the office, because they were Malays, I could not talk to my former schoolmates, because they were all Chinese. I was just alone, literally, and utterly alone" (Libdenberg 2009, p. 232). She also reports a Malay Muslim man who married a Chinese girl: "After several months, four months or so, it became difficult. The parentsin-law, the mental picture they have of Chinese is still different, they think that their hands are still full of ... impurity (haram) with pork, they will not let their daughterin-law cook. My mother was checking her, she felt uncomfortable when she prepared the food" (Libdenberg 2009, p. 231). She reports that verbal or physical violence was also encountered by interfaith couples (Libdenberg 2009, p. 230). Jolanda quotes Dea that "religions seem to connect believers across ethnic boundaries, but simultaneously, it paradoxically divides neighbors and relatives" (Libdenberg 2009, p. 246).

\section{Conclusion}

As a matter of fact, it is difficult to live in harmony with a different culture, let alone a different religion. Sometimes a tiny subject may trigger disputes and problems. So it would be better to marry a woman or a man from the same culture and religion as suggested by the Hanafi scholars under the pretext kafä'at 'equality, suitability' (alMarghinānī 1971, Vol. 1, pp. 200-202). Although some scholars may issue fatwas in favour of interreligious marriages, the couples should not forget that not only they but also their respective families and friends are involved in the marriage. As the prophet said, "ask your heart" (Ahmed b. Hanbel 1992: Musnad 4: 228): if you are ready to challenge religious, legal and social issues, go ahead with your love. Otherwise think twice.

One who has no choice other than marriage may follow the view of the scholars who permit such marriage. To put it another way, the marriage of a Muslim woman to an ahl al-kitäb man can be considered valid in dire necessity conditions. ${ }^{37}$ The Prophet is reported to have said, "difference of opinion among my people is a sign of the bounty of God". 38

As we have seen, the Supreme Court of Massachusetts and the Supreme Court of Indonesia examined interfaith marriage. While the Supreme Court of Massachusetts endorsed the $\operatorname{shari~}^{`} a$ law of the Ottoman Empire annulling the marriage of a con-

\footnotetext{
${ }^{37}$ The Oxford Times reports that Dr Taj Hargey, chairman of the Muslim Education Centre of Oxford, has been performing interfaith marriages. He said, he had performed about 36 marriages between Muslim women and non-Muslim men. He is reported to have said: "We do it because there is no prohibition in the Koran. Islam allows Muslim men to marry non-Muslim women and such marriages are common, but I am one of the only people who will do it the other way round" (http://www.oxfordtimes.co.uk/news/4423688.Imam bridges a wedding_divide/).

${ }^{38}$ al-'Ajlūnī mentions different views on the authenticity of this hadīth. For more, see al‘Ajlūnī (1988, Vol. 1, pp. 64-66). 
vert, the Supreme Court of Indonesia endorsed the interfaith marriage on the basis of human rights disregarding the rules of the $\operatorname{sharī'}^{\prime} a$ law. It seems that interfaith marriage disputes will continue to occupy the premises of the law courts for the foreseeable future.

\section{References}

Abdullah An-Na‘īm. At: http://www.irandokht.com/editorial/index4.php?area=wor\&sectionID=24 \&editoria $1 \mathrm{ID}=2105$.

Acar, H. İ. Evlenme Engeli Olarak Din Farkı. At: http://e-dergi.atauni.edu.tr/index.php/ilahiyat/ article/viewFile/3051/2944.

Ahmed b. Hanbel (1992): Musnad. Istanbul, Cağrı Yayınları.

al-‘Ajlūn̄̄ (1988): Kashf al-Khafā. Vol. 1. Beirut, Dār al-kutub al-‘ilmiyya.

Aktan, H. (2002): Güncel dini meseleler istişare toplantısı I. Istanbul, Diyanet İşleri Başkanlığı Yayınları.

al-Askalānī, Aḥmad b. 'Alī b. Khajar (1407/1986-1987): Fath al-Bārī. Vol. 9. Cairo, Dār al-Bayān.

Atay, H. (1993): Kur'an'a Göre Arastırmalar I. Ankara, Semih Ofset Matbaacilık.

Ateş, S. (2006): Vatan Gazetesi 03.02.2006.

Aydın, M. A. (1985): Íslam-Osmanlı Aile Hukuku. Istanbul, Marmara Üniversitesi İlahiyat Fakültesi Yayınlar1.

Bilgin, B. (2001): İslam 'da Kadının Rolü. Türkiye'de Kadın. Ankara.

Bilmen, Ö. N. (1985): Hukuku İslamiyye ve Istılahatı Fıkhiyye Kamusu. Istanbul, Bilmen Basımevi. Blackstone, W. (1966): Commentaries on the Laws of England. Oxford, Clarendon Press.

Bukhāri (1992): Saḥ̄ḥ al-Bukhāri. Istanbul, Çağrı Yayınları.

Cammack, M. (2009): Legal Aspects of Muslim Non-Muslim Marriage in Indonesia. In: Jones, Gavin W.-Leng, Chee Heng-Mohamad, Maznah (eds): Muslim Non-Muslim Marriage: Political and Cultural Contestations in Southeast Asia. Singapore, Iseas.

Canan, I.: Cizye ile ilgili hükümler. http://www.hadis.resulullah.org/index.php?s=oku\&id=2969.

Cholil, S. (2009): The Politico-religious Contestation: Hardening of the Islamic Law on Muslim non-Muslim Marriage in Indonesia. In: Jones, Gavin W.-Leng, Chee Heng-Mohamad, Maznah (eds): Muslim Non-Muslim Marriage: Political and Cultural Contestations in Southeast Asia. Singapore, Iseas.

Çiğdem, Recep (2001): The Register of the Law Court of Istanbul 1612-1613: A Legal Analysis. The University of Manchester (Unpublished PhD Thesis).

Çiğdem, R. (2011): A Descriptive Study of the Registers of The Ottoman Law Courts Preserved at the St. St. Cyril and Methodius National Library with an Introduction to the Muslim Minority Courts between 1878-1945 in Bulgaria. Şanlıurfa, İlahiyat Fakültesi Geliştirme Vakfi.

Cretney, M. S. - Masson, M. J. (1997): Principles of Family Law. London, Sweet \& Maxwell.

Dağcı, Ş. (2000): İslam Aile Hukunda Evlenme Engelleri - II. Ankara Üniversitesi İlahiyat Fakültesi Dergisi Vol. 41, pp. 137-194.

Dalgın, N. (2003): İslam Hukuku Açısından Müslüman Bayanın Ehli Kitap Erkekle Evliliği. İslam Hukuku Araştırmaları Dergisi Vol. 2, pp. 131-156.

Dalgın, N. (2005): Müslüman Gayri Müslim Evliliği. Samsun, Etüd Yayınları.

Düzdağ, E. M. (1972): Şeyhülislam Ebussuud Efendi Fetvaları Işığında 16. Asır Türk Hayatı. Istanbul, Enderun Kitabevi. 
Eren, M., A: İşte bizim Yahudiler. At: http://www.aksiyon.com.tr/aksiyon/haber-5370-34-iste-bizimyahudiler.html.

Eskan, S. (2007): İslam Aile Hukukunda Evlilik Engeli Olarak Din Farkı Problemi. Atatürk University, The Institute of Social Sciences (Unpublished PhD Thesis).

Fakhr al-Dīn al-Rāzī (1981): Mafātih al-Ghayb. Vol. 6. Beirut, Dār al-Fikr.

Feuer, A. (2004): Vatican Frowns on Muslim Intermarriage. Deseret News (Utah), May 15, 2004, at A4. = http://www.worthynews.com/9748-pakistan-interfaith-couple-in-hiding-amid-deaththreats.

Gradeva, R. (1997): Orthodox Christians in the Kadi Courts: The Practice of the Sofia Sheriat Court, Seventeenth Century. Islamic Law and Society Vol. IV, No. 1 (January), pp. 37-69.

Güler, İ. (1997): Kuran'da Kadın Erkeğin Eşitsizliğinin Temelleri. İslami Araştırmalar Vol. 10, No. 4, pp. 310-319; http://www.islamiarastirmalar.com/upload/pdf/731 eaab7fed1df2.pdf.

Gündüz, S. (2002): Ehli Kitab'ın Kimliği Sorunu ve Ebû Hanîfe ile Çağdaşlarının "kitab” Terimi Merkezli Yaklaşımları. İslamî Araştırmalar Vol. 15, Nos 1-2, pp. 241-245.

al-Halabī, Ibrahim (1981): Multaqā al-Abhūr. Istanbul, Güryay Matbaası.

Hamidullah, M. (1991): İslam Peygamberi. Tug, S. (trans.). İstanbul, İrfan Yayıcıllk ve Ticaret. http://en.wikipedia.org/wiki/Interfaith_marriage_in_Christianity.

http://en.wikipedia.org/wiki/Interfaith_marriage_in_Islam.

http://www.agc.gov.my/Akta/Vol.\%207/Act\%20303.pdf.

$\mathrm{http} / / / \mathrm{www}$.asianews.it/news-en/Muslim-woman-forced-to-flee-for-marrying-a-Christian-22162.html. http://www.jewishjournal.com/los_angeles/article/rabbi_reverses_interfaith_marriage_policy.

http://www.oxfordtimes.co.uk/news/4423688.Imam_bridges_a_wedding_divide/

http://www.sistani.org/index.php?p=741491\&id=56\&pid=3263.

Ibn Humām, Kamāl al-Dīn (no date): Fath al-Qādir. Vols 1-10. Beirut, Dār al-Fikr.

Ibn Nujaym (1985): Al-Ashbāh wa al-Nazā'ir. Vol. 1. Beirut, Dār al-Maktaba al-'Ilmiyya.

Ibn Nujaym (1992): Baḥr al-Rā'iq. Vol. 3. Beirut, Dār al-kutub al-'ilmiyya.

Ibn Qudāma, 'Abdullāh b. Aḥmad (1992): Al-Mughnī. Vol. 10. Beirut, Dār al-Fikr.

Ibn Rushd, Muhammad b. Aḥmad (no date): Bidāyat al-Mujtahid wa Nihāyat al-Muqtasid. Vol. 2. Beirut, Dār al-Fikr.

al-Jassās, Abū Bakr Aḥmad b. 'Alī Al-Rāzī (1985): Aḥkām al-Qur'ān. Beirut, Dār iḥyā al-turāth al'arabī.

al-Jazīin̄, Abdurraḥman (1986): Kitāb al-Fiqh 'alā al-Maz̄āhib al- 'Arba 'a. Istanbul, Çağrı Yayınları. Karaman, H. (1996): Mukayeseli İslam Hukuku. Vols 1-3. Istanbul, Nesil Yayınları.

Kaya, F. Ş. (1999): İstanbul Yahudilerinin Kimlik Tanımlamaları Üzerine Bir Alan Araştırması. Istanbul University, The Institute of Social Sciences (Unpublished PhD Thesis).

Kökelekli, H. - Çayır, C. (2006): Gençlerin Din Değiştirip Hıristiyan Olmasında Etkili Olan PsikoSosyal Etkenler. Uludă̆ Üniversitesi, İlahiyat Fakültesi Dergisi Vol. 15, No. 1, pp. 23-46 (http://home.uludag.edu.tr/users/ucmaz/PDF/ilh/2006-15(1)/M2.pdf).

Kuzgun, Ş. (1985): İslâm Kaynaklarına Göre Hz. İbrahim ve Haniflik. Kayseri, Seda Yayınları.

Leeman, B. A. (2009): Interfaith Marriage in Islam: An Examination of the Legal Theory Behind the Traditional and Reformist Positions. Indiana Law Journal Vol. 84, No. 2, pp. 759-761.

Lemmons, E.: Interfaith Marriages At: http://foryourmarriage.org/catholic-marriage/church-teachings/ interfaith-marriages/.

Libdenberg, J. (2009): Interethnic Marriages and Conversion to Islam in Kota Bharu. In: Jones, Gavin W.-Leng, Chee Heng-Mohamad, Maznah (eds): Muslim Non-Muslim Marriage: Political and Cultural Contestations in Southeast Asia. Singapore, Iseas.

Lukito, R. (2009): Trapped between Legal Unification and Pluralism: The Indonesian Supreme Court's Decision on Interfaith Marriage. In: Jones, Gavin W.-Leng, Chee Heng-Moha- 
mad, Maznah (eds): Muslim Non-Muslim Marriage: Political and Cultural Contestations in Southeast Asia. Singapore, Iseas.

Malhotra, A. - Malhotra, R.: Family Law And Religion - The Indian Experience. At: http://www. iaml.org/cms_media/files/family_law_and_religion_the_indian_experience.pdf.

Malik b. Anas (1992): Muwațtā, Istanbul, Çağrı Yayınları.

al-Marghinānī, Burhān al-Dīn (1986): al-Hidāya. Vols 1-4. İstanbul, Kahraman Yayınları.

Mohamad, M. - Aziz, Z. - Sim, C. O. (2009): Private Lives, Public Contestation, Muslim Non-Muslim Family Disputes in Malaysia. In: Jones, Gavin W.-Leng, Chee Heng-Mohamad, Maznah (eds): Muslim Non-Muslim Marriage: Political and Cultural Contestations in Southeast Asia. Singapore, Iseas.

Mulia, S. M. (2009): Promoting Gender Equity through Interreligious Marriage Empowering Indonesian Women. In: Jones, Gavin W. - Leng, Chee Heng - Mohamad, Maznah (eds): Muslim Non-Muslim Marriage: Political and Cultural Contestations in Southeast Asia. Singapore, Iseas.

Noor Aisha Abdul Rahman (2009): Muslim-Non-Muslim Marriage in Singapore. In: Jones, Gavin W. - Leng, Chee Heng-Mohamad, Maznah (eds): Muslim Non-Muslim Marriage: Political and Cultural Contestations in Southeast Asia. Singapore, Iseas.

No author, Forbidden Sexual Relations - Issurei Biah. At: http://www.torah.org/learning/halachaoverview/chapter27.html.

No author, Interfaith Marriage. At: http://en.wikipedia.org/wiki/Interfaith_marriage\#cite_ref-Jew EncInter 3-0.

No author, Intermarriage. At: http://www.jewishencyclopedia.com/articles/8137-intermarriage.

Oliphant, E. R. - Steegh, V. N. (2007): Family Law. Second edition, New York, Aspen Publishers.

Özevin, A. (2006): Süleyman Ateş'in Yüce Kur'an'ın Çağdaş Tefsiri adlı eserinde ehl-i kitap ve yorum. Cukurova University, The Institute of Social Sciences (Unpublished MA Theses).

Peker, H. (1979): Din değiştirmede psiko-sosyolojik etkenler. Ankara University, The Institute of Social Sciences (Unpublished PhD Thesis).

Qanta, A. A: Islam, interfaith marriage go hand in hand. At: http://usatoday30.usatoday.com/news/ opinion/forum/story/2012-02-12/islam-muslim-interfaith-marriage/53062730/1.

Ramazan effendi (no date): Sharh li Ramazan efendi 'alā sharh al-Aqāid. Istanbul, Salah Bilici Kitapevi.

Rashīd Riḍā (1367/1948): Tafsīr al-Qur'ān al- Hakīm (Tafsìr al-Manār). Vol. VI. Cairo, Dār alManār.

Reed, A. (2003): Anglo-American Perspectives on Private International Law. Lewiston, N.Y., The Edwin Mellen Press.

Sābūni, Muhammad Ali: Mukhtasar Tafsīr-i Ibn Kathīr. Vol. 1. Dersaadet.

Saifuddin, E.: Interfaith Marriages: Why Can't a Muslim Woman Marry a Non-Muslim Man? At: http://peopleofsunnah.com/fiqh/rulings/marriage/80-interfaithmarriage.

al-Sarakhsī, Shams al-Dīn (1986): Al-Mabsūt. Vol. 5. Beirut, Dār al-Ma'rifa.

Schwartz, A.: The Emotional Challenges of Interfaith Marriage. At: http://psychcentral.com/lib/ 2006/the-emotional-challenges-of-interfaith-marriage/all/1/.

al-Shirbīnī al-Khatībī, Muḥammad (1958): al-Mughnī al-Muhtāj ilā Ma 'rifat Ma 'ānī al-Alfāz alMinhāj. Vol. 4. Cairo, Mața'a Muștafā al-Halabī.

The Cairo Declaration of Human Rights (CDHR). At: http://www1.umn.edu/humanrts/instree/ cairodeclaration.html.

The Holy Bible, The Old and New Testaments: Revised Standard Version (1952). New YorkGlasgow, Collin's Clear Type Press.

The Holy Qur'ān. At: www.kuran.gen.tr. 
The Universal Declaration of Human Rights (UDHR). At: http://www.un.org/en/documents/udhr/ index.shtml.

Topçuoğlu, A. A. (2010): Yahudilik, Hıristiyanlık Ve İslam Hukukuna Göre Nikah Akdine Etkisi Bakımından Din Farklılı̆̆ı. Din Bilimleri Akademi Araştırma Dergisi Vol. 10, No. 2, pp. 79-120. (http://www.dinbilimleri.com/Makaleler/676199355_1002040074.pdf).

Tümer, G. - Küçük, A. (1993): Dinler Tarihi. Ankara, Ocak Yayınları.

Walter, H. C.: A Catholic Priest's Perspective on Interfaith Marriage. At: http://www.interfaith family.com/life_cycle/weddings/A_Catholic_Priests_Perspective_on_Interfaith_Marriage. shtml. 